\title{
Short communication \\ Do classical oestrogen markers predict for clinical response to endocrine therapy?
}

\author{
William R Miller
}

Breast Unit, Paderewski Building, Western General Hospital, Edinburgh, EH4 2XU, UK

Corresponding author: William R Miller, wmiller@staffmail.ed.ac.uk

Published: 20 December 2007

This article is online at http://breast-cancer-research.com/content/9/S2/S19

(c) 2007 BioMed Central Ltd

\section{Introduction}

Oestrogen may maintain the growth of some breast cancers, and oestrogen deprivation therapy can cause tumour regression. However, even in breast cancers that possess oestrogen receptors (the key transcription factor in oestrogen signalling), response rates to endocrine therapy are only $50 \%$ to $60 \%$, hence the interest in identifying additional factors that might predict response/resistance to hormone therapy. In this respect, it had been hoped that molecules that are regulated by oestrogen would be excellent candidates. However, this review makes the case that oestrogenregulated markers are unlikely to be robust indicators of hormone dependence in breast cancers.

Evidence is based on correlating oestrogen regulated markers (identified on account of having an oestrogen response element [ERE] in the promoter region of their genes and being classically oestrogen regulated in many hormonesensitive tissues [the example used is the progesterone receptor $(\mathrm{PR})$ ], expression being regulated by oestrogen in breast cancer cell lines, and expression being regulated by oestrogen deprivation therapy in primary breast cancers) with clinical response to endocrine therapy either in patients with advanced breast cancer or in the neoadjuvant setting.

\section{Progesterone receptor and clinical response to neoadjuvant hormone therapy}

Two major randomized trials of neoadjuvant endocrine therapy (P024 and IMPACT [Immediate Preoperative Arimidex Compared to Tamoxifen]) and one other large study assessed the relationship of PR status to clinical response to either tamoxifen or an aromatase inhibitor. All found a higher incidence of PR positivity in clinically responding tumours [1-3] as compared with nonresponders. However, it is clear that a substantial number of PR-negative tumours respond to endocrine therapy, and conversely that many clinical nonresponding tumours possess PR. Consequently, PR is a poor marker of clinical response to endocrine therapy.

It could be argued that rather than measure pretreatment PR expression, it might be more informative to relate change in
Breast Cancer Research 2007, 9(Suppl 2):S19 (doi:10.1186/bcr1817)

PR level with clinical response. Treatment with aromatase inhibitors is associated with a reduction in immunohistochemical staining for PR [1-3]. However, this occurs in about $90 \%$ of cases irrespective of clinical response. It is clear that downregulation of PR occurs in most clinically nonresponsive tumours.

\section{Genes regulated by oestrogen in breast cancer cell lines}

Many studies have been conducted to determine the effects of oestrogen addition/withdrawal in breast cancer cell lines maintained in culture or as xenografts in immunosuppressed animals; most have used the MCF7 cell line. Five studies published since 2000 [4-8] have been used as a database in which to identify oestrogen-regulated genes. No single gene was listed in all five publications, but two were quoted in four publications and nine in at least three journals. A total of 141 genes were confirmed by publication in two journals. The general lack of consensus probably reflects variables such as the amount of oestrogen used, duration of exposure, different sources of cell lines, conditions of growth and different platforms of assays. These 141 genes were compared with the gene signatures based on a pretreatment tumour analysis from patients with advanced breast cancer and predicting response to tamoxifen, as defined by Janssen and coworkers [9]. The overlap between the genes was minimal. However, such a comparison is based upon change in expression for the cell line gene set and pretreatment expression for the clinical response signature.

To avoid this confounder, the 141 gene list has been compared with genes that most significantly changed on letrozole neoadjuvant treatment but differentially expressed between responders and nonresponders [10]. No correlation was found between the two sets of genes. Although the identity of these genes remains unreported, none were found among the 141 regulated by oestrogen in the MCF7 cell line. There are two major reasons for this. First, some genes change in both nonresponding and responding cases. Second, some genes change in culture following oestrogen 


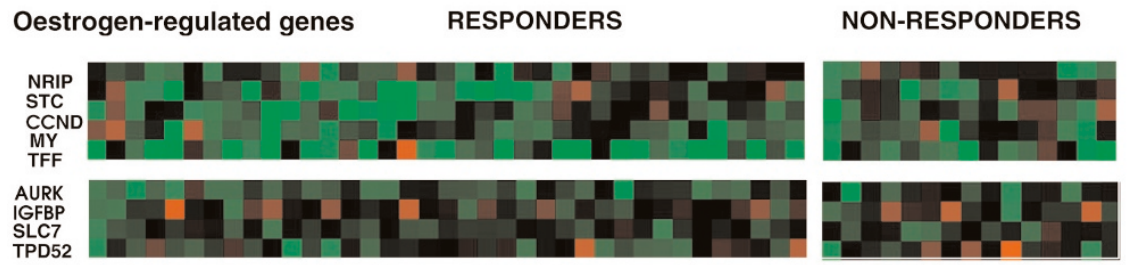

House-keeping genes

ACTB

GAPDH

exposure/withdrawal but are relatively unaffected by letrozole treatment in primary tumours. This can be illustrated, as is shown in Figure 1, by comparing the change in expression of the nine most commonly quoted oestrogen-regulated genes in MCF7 in responding and nonresponding tumours. It can be seen that genes such as NRIP1, STC2, CCND1, MYB and TFF1 are frequently downregulated by letrozole treatment in clinically responding tumours, but this also occurs in many of the nonresponding cases. Other genes such as $A U R K A$, IGFBP4, SLC7A5 and TPD52-1 are relatively unaffected by treatment in both responders and nonresponders.

\section{Genes that are influenced by endocrine therapy in breast cancer}

A list of genes most significantly influenced by neoadjuvant treatment (at 14 days) with letrozole has been published [10]. However, this has no overlap with genes whose expression is differentially changed between clinical responders and nonresponders at the same time point (unpublished data). The reason for this is that expression levels of oestrogen-regulated genes are changed by therapy per se and are not restricted to clinically responding tumours, and also change in clinically resistant cases. Accurate prediction of clinical response requires a novel gene discovery programme to identify markers that are regulated by oestrogen in clinically responding tumours alone (or conversely in clinically resistant tumours alone).

It is concluded that oestrogen-regulated genes are molecular markers of oestrogen sensitivity (not dependence); that expression profiles and molecular responses to endocrine therapy in clinically resistant tumours may be similar to clinical responders; and, therefore, that most oestrogen-regulated genes are unlikely to be robust markers of clinical response to endocrine therapy.

\section{Acknowledgement}

This article has been published as part of Breast Cancer Research Volume 9 Supplement 2, 2007: Controversies in Breast Cancer. The full contents of the supplement are available online at http://breastcancer-research.com/supplements/9/S2.

\section{References}

1. Ellis MJ, Coop A, Singh B, Mauriac L, Llombert-Cussac A, Janicke $\mathrm{F}$, Miller WR, Evans DB, Dugan M, Brady C, et al.: Letrozole is more effective neoadjuvant endocrine therapy than tamoxifen for ErbB-1- and/or ErbB-2-positive, estrogen receptor-positive primary breast cancer: evidence from a phase III randomized trial. J Clin Oncol 2001, 19:3808-3816.

2. Dowsett M, Ebbs SR, Dixon JM, Skene A, Griffith C, Boeddinghaus I, Salter J, Detre S, Hills M, Ashley S, et al:: Biomarker changes during neoadjuvant anastrozole, tamoxifen, or the combination: influence of hormonal status and HER-2 in breast cancer: a study from the IMPACT trialists. J Clin Oncol 2005, 23:2477-2492.

3. Miller WR, White S, Dixon JM, Murray J, Renshaw L, Anderson TJ: Proliferation, steroid receptors and clinical/pathological response in breast cancer treated with letrozole. $\mathrm{Br} J$ Cancer 2006, 94:1051-1056.

4. Charpentier AH, Bednarek AK, Daniel RL, Hawkins KA, Laflin KJ, Gaddis S, MacLeod MC, Aldaz CM: Effects of estrogen on global gene expression: identification of novel targets of estrogen action. Cancer Res 2000, 60:5977-5983.

5. Frasor J, Danes JM, Komm B, Chang KC, Lyttle CR, Katzenellenbogen BS: Profiling of estrogen up- and down-regulated gene expression in human breast cancer cells: insights into gene networks and pathways underlying estrogenic control of proliferation and cell phenotype. Endocrinology 2003, 144:4562-4574.

6. Inoue A, Yoshida N, Omoto Y, Oguchi S, Yamori T, Kiyama R, Hayashi S: Development of cDNA microarray for expression profiling of estrogen-responsive genes. J Mol Endocrinol 2002, 29:175-192.

7. Oh DS, Troester MA, Usary J, Hu Z, He X, Fan C, Wu J, Carey LA, Perou CM: Estrogen-regulated genes predict survival in hormone receptor-positive breast cancers. J Clin Oncol 2006, 24:1656-1664.

8. Creighton CJ, Cordero KE, Larios JM, Miller RS, Johnson MD, Chinnaiyan AM, Lippman ME, Rae JM: Genes regulated by estrogen in breast tumor cells in vitro are similarly regulated in vivo in tumor xenografts and human breast tumors. Genome Biol 2006, 7:R28.

9. Jansen MP, Foekens JA, van Staveren IL, Dirkzwager-Kiel MM, Ritstier K, Look MP, Meijer-van Gelder ME, Sieuwerts AM, Portengen $\mathrm{H}$, Dorssers LC, et al:: Molecular classification of tamoxifenresistant breast carcinomas by gene expression profiling. $J$ Clin Oncol 2005, 23:732-740.

10. Miller WR, Larionov A, Renshaw L, Anderson TJ, White S, Hampton G, Walker JR, Ho S, Krause A, Evans DB, et al.: Aromatase inhibitors: gene discovery. J Steroid Biochem Mol Biol 2007, 106:130-142. 